\title{
Polyphasic Analysis of Strains of the Genus Capnocytophaga and Centers for Disease Control Group DF-3
}

\author{
P. VANDAMME, ${ }^{1,2 *}$ M. VANCANNEYT, ${ }^{1}$ A. VAN BELKUM,${ }^{3}$ P. SEGERS, ${ }^{1}$ W. G. V. QUINT, ${ }^{4}$ \\ K. KERSTERS, ${ }^{1}$ B. J. PASTER, ${ }^{5}$ AND F. E. DEWHIRST ${ }^{5}$ \\ Laboratory of Microbiology, University of Ghent, Ghent, ${ }^{1}$ and Department of Microbiology, University Hospital \\ Antwerp UIA, Antwerp, ${ }^{2}$ Belgium; Department of Bacteriology, University Hospital Rotterdam, Rotterdam, ${ }^{3}$ \\ and Department of Molecular Biology, Diagnostic Center SSDZ, Delft, ${ }^{4}$ \\ The Netherlands; and Department of Molecular Genetics, Forsyth \\ Dental Center, Boston, Massachusetts 02115
}

\begin{abstract}
A polyphasic approach was used to determine the relationships between well-characterized reference strains representing all seven Capnocytophaga species. One Centers for Disease Control (CDC) group DF-3 strain, a presumed relative of the genus Capnocytophaga, and 15 field isolates were included as well. Fourteen isolates were assigned to named Capnocytophaga species, all of which could be differentiated by means of whole-organism protein electrophoresis. A separate position was occupied by the CDC group DF-3 strain and by one field isolate representing a novel Capnocytophaga species. The phylogenetic position of each taxon was determined by means of 16S rRNA sequence analysis. A considerable genotypic heterogeneity within the genus Capnocytophaga was detected in spite of the minimal phenotypic differences. Comparative 16S rRNA sequence analysis revealed that CDC group DF-3 is not a close relative of the capnocytophagas but constitutes a separate genus that clusters together with Bacteroides forsythus and Bacteroides distasonis, two generically misclassified Bacteroides species. The degree of protein similarity correlated with our and published DNA-DNA binding values. Percentage 16S rRNA similarity values of greater than 97\% did not guarantee conspecificity. All Capnocytophaga strains had very similar fatty acid contents characterized by significant amounts of 14:0, 15:0 iso (greater than 55\%), 16:0, 16:0 30H, and 17:0 iso 3OH. PCR-mediated DNA fingerprinting allowed discrimination of most species, although some strains could not be classified efficiently because of DNA polymorphisms.
\end{abstract}

In 1979, Leadbetter and coworkers proposed the genus Capnocytophaga for a group of gram-negative, fusiform, microaerophilic, fermentative, and gliding bacteria that were isolated from the oral cavities of healthy and diseased humans (27). At that time, the synonymy between Capnocytophaga and the Centers for Disease Control (CDC) group DF-1 (disgonic fermenter 1) and between Capnocytophaga ochracea and Bacteroides ochraceus was established $(29,52)$. From early on, the delineation of species within the genus Capnocytophaga was controversial since two of the three species, i.e., C. ochracea and Capnocytophaga sputigena, were virtually indistinguishable. Classical phenotypic tests or analysis of enzymatic capacities did not allow a satisfactory species delineation $(22,25-27$, 38 ). However, only low DNA-DNA hybridization values were measured between reference strains of both species $(39,51)$. The application of various chemotaxonomic markers did not elucidate this problem. Not only $C$. ochracea and $C$. sputigena but also Capnocytophaga gingivalis was indistinguishable in analyses of their fatty acid contents $(6,9,21,39)$, polar lipid contents (6), and respiratory quinone contents (6, 39 [all strains contain menaquinone- 6 and trace amounts of menaquinone-5]). Protein profiling of 97 field isolates and the type strains of each species allowed distinction of eight distinct clusters, three of them containing one type strain each (24). Recently, Wilson et al. (53) performed restriction fragment length polymorphism analyses of PCR-amplified 16S rDNA genes which also confirmed the separate species status of the three taxa.

\footnotetext{
* Corresponding author. Mailing address: Laboratorium voor Microbiologie, Ledeganckstraat 35, B-9000 Ghent, Belgium. Phone: (32) 9.264.51.14. Fax: (32) 9.264.53.46. Electronic mail address: Peter.Van damme@rug.ac.be.
}

Ten years after the description of the first three species, two additional species isolated from dog mouths and from wound infections after dog bites were proposed: Capnocytophaga canimorsus (formerly known as CDC group DF-2) and Capnocytophaga cynodegmi (formerly known as CDC group DF-2-like) (4). These last two species differed from the others by the presence of catalase and oxidase activities, but their general phenotypic profile conformed to the genus description (4). Furthermore, the fatty acid $(8-10,39)$ and respiratory quinone profiles (39) of the former CDC group DF-2 were indistinguishable from those of $C$. ochracea, $C$. sputigena, and C. gingivalis. Finally, Capnocytophaga haemolytica and Capnocytophaga granulosa were described by Yamamoto et al. (56). These species were isolated from the human oral cavity and share the same fatty acid and quinone components and general biochemical profile with other human Capnocytophaga species (56).

Suprageneric studies by means of DNA-rRNA hybridizations revealed that the genus Capnocytophaga constitutes a separate phylogenetic branch within rRNA superfamily V (37). Comparative 16S rRNA sequence analysis situated the genus Capnocytophaga within the so-called cytophaga subgroup of the flavobacter-bacteroides phylum of bacteria $(13,18,46)$. The capnophilic genera Capnocytophaga, Ornithobacterium, and Riemerella all belong to the same lineage and were included in the emended family Flavobacteriaceae (3).

CDC group DF-3 (dysgonic fermenter 3) is a group of unclassified gram-negative rods resembling the other dysgonic fermenters which are now classified as Capnocytophaga species. DF-3 strains have been isolated from various human clinical sources and share several biochemical and chemotaxonomic properties with Capnocytophaga strains $(2,50)$. However, their phylogenetic affiliation is unknown.

In the present study, we used a polyphasic approach to determine the relationships between well-characterized refer- 
TABLE 1. Strains used in this study

\begin{tabular}{|c|c|c|}
\hline Strain $^{a, b}$ & Other numbers ${ }^{a, b}$ & Source, year, and place of isolation ${ }^{c}$ \\
\hline \multicolumn{3}{|l|}{ Reference strains } \\
\hline C. canimorsus ATCC $35979^{\mathrm{T}}$ & CDC $7120^{\mathrm{T}}$ & Human blood after dog bite; United States \\
\hline C. canimorsus LMG 11510 & CCUG 12569, CDC A3626 & Human blood; 1965; United States \\
\hline C. canimorsus LMG 11512 & CCUG 24741, CDC C8936 & Human blood after dog bite; United States \\
\hline C. canimorsus LMG 11541 & MCCM 00060, CDC C8936 & Human blood after dog bite; United States \\
\hline C. cynodegmi LMG $11513^{\mathrm{T}}$ & CCUG $24742^{\mathrm{T}}$, CDC E6447", ATCC $49044^{\mathrm{T}}$ & Dog mouth; 1979; United States \\
\hline C. cynodegmi LMG 11538 & MCCM 00262, CDC E679 & Hand wound; United States \\
\hline C. cynodegmi LMG 11539 & MCCM 00263, CDC F4039 & \\
\hline C. cynodegmi LMG $11540^{\mathrm{T}}$ & MCCM $00265^{\mathrm{T}}$, CDC E6447 , ATCC $49044^{\mathrm{T}}$ & Dog mouth; 1979; United States \\
\hline C. gingivalis LMG $11514^{\mathrm{T}}$ & CCUG $9715^{\mathrm{T}}$, Holt $27^{\mathrm{T}}$, ATCC $33624^{\mathrm{T}}$ & Periodontitis; 1978; United States \\
\hline C. granulosa $\mathrm{LMG} 16022^{\mathrm{T}}$ & JCM $8566^{\mathrm{T}}$ & Adult supragingival dental plaque; Japan \\
\hline C. haemolytica LMG $16021^{\mathrm{T}}$ & $\mathrm{JCM} 8565^{\mathrm{T}}$ & Adult supragingival dental plaque; Japan \\
\hline C. ochracea ATCC $27872^{\mathrm{T}}$ & & Human oral cavity \\
\hline C. ochracea LMG 11516 & CCUG 9972, VPI 13316 & $\begin{array}{l}\text { Bülow drain secretion (pulmonary cancer); } \\
\text { 1980; Sweden }\end{array}$ \\
\hline C. ochracea LMG 11546 & CCUG 15407, Holt 25, ATCC 33596 & Periodontitis; 1978; United States \\
\hline C. ochracea LMG 11977 & HIM 779-6 & Periodontitis; 1982; Germany \\
\hline C. sputigena $\mathrm{LMG} 11518^{\mathrm{T}}$ & CCUG $9714^{\mathrm{T}}$, Holt $4^{\mathrm{T}}$, ATCC $33612^{\mathrm{T}}$ & Periodontitis; 1978; United States \\
\hline C. sputigena LMG 11517 & CCUG 9277, VPI 13197 & Human blood; 1979; Sweden \\
\hline DF-3 LMG 11519 & CCUG 17996, CDC F9047 & Cutaneous abscess; 1985; Denmark \\
\hline \multicolumn{3}{|l|}{ Field isolates } \\
\hline Capnocytophaga sp. LMG 11511 (C. canimorsus) & CCUG 17234, P810 & \\
\hline Capnocytophaga sp. LMG 11551 (C. canimorsus) & MCCM 01373 & Human blood; 1990; Switzerland \\
\hline Capnocytophaga sp. LMG 11505 (C. gingivalis) & CCUG 13095 & Periodontitis; 1982; Sweden \\
\hline Capnocytophaga sp. LMG 12118 (C. gingivalis) & FDC 44 & Human subgingival crevice; United States \\
\hline Capnocytophaga sp. LMG 11544 (C. ochracea) & HIM 1017-2 & Sheep \\
\hline Capnocytophaga sp. LMG 12115 (C. ochracea) & FDC 7 & Human subgingival crevice; United States \\
\hline Capnocytophaga sp. LMG 12117 (C. ochracea) & FDC 43 & Human subgingival crevice; United States \\
\hline Capnocytophaga sp. LMG 11506 (C. granulosa) & CCUG 14446 & Human oral cavity; 1983; Sweden \\
\hline Capnocytophaga sp. LMG 11507 (C. granulosa) & CCUG 14447 & Human oral cavity; 1983; Sweden \\
\hline Capnocytophaga sp. LMG 11515 (C. granulosa) & CCUG 12286, VPI 13779 & $\begin{array}{l}\text { Gingivum from a healthy individual; 1982; } \\
\text { Sweden }\end{array}$ \\
\hline Capnocytophaga sp. LMG 12119 (C. granulosa) & FDC 6 & Human subgingival crevice; United States \\
\hline Capnocytophaga sp. LMG 11545 (C. sputigena) & CCUG 17163 & Human blood; 1984; Sweden \\
\hline Capnocytophaga sp. LMG 11509 (C. sputigena) & CCUG 17222 & Human blood; 1984; Sweden \\
\hline Capnocytophaga sp. LMG 11508 (C. sputigena) & CCUG 15264, CDC F1659 & Human blood; United States \\
\hline Capnocytophaga sp. strain LMG 12116 (new species) & FDC 8 & Human subgingival crevice; United States \\
\hline
\end{tabular}

${ }^{a}$ Type strains are indicated by superscript T. Names in parentheses indicate how field isolates have been identified.

${ }^{b}$ CCUG, Culture Collection of the University of Göteborg, Department of Clinical Bacteriology, University of Göteborg, Göteborg, Sweden; CDC, Centers for Disease Control, Atlanta, Ga.; FDC, Forsyth Dental Center, Boston, Mass.; HIM, Hygiene-Institut und Medizinal-Untersuchungsamt, University of Marburg, Marburg, Germany; JCM, Japan Collection of Microorganisms, Institute of Physical and Chemical Research, Saitama, Japan; LMG, Culture Collection Laboratorium voor Microbiologie, University of Ghent, Ghent, Belgium; MCCM, Medical Culture Collection of Microorganisms, Marburg, Germany; VPI, Virginia Polytechnic Institute and State University, Blacksburg, Va.

${ }^{c}$ If known.

ence strains representing all 7 Capnocytophaga species and 15 field isolates. One representative (50) CDC group DF-3 strain was included as well.

\section{MATERIALS AND METHODS}

Bacterial strains and growth conditions. All strains were grown on Trypticase soy agar (catalog no. 11768; BBL, Becton Dickinson Microbiology Systems, Cockeysville, Md.) and were incubated at 36 to $37^{\circ} \mathrm{C}$ in a microaerobic atmosphere containing approximately $5 \% \mathrm{O}_{2}, 3.5 \% \mathrm{CO}_{2}, 7.5 \% \mathrm{H}_{2}$, and $84 \% \mathrm{~N}_{2}$. The strains and their sources are listed in Table 1. Type strains and strains included in previous taxonomic studies are considered reference strains; all others are referred to as field isolates. Bacteriological purity was checked by plating and examining living and gram-stained cells.

Whole-cell protein analysis. All strains were grown for $48 \mathrm{~h}$ on one to three petri dishes. Preparation of cellular protein extracts, polyacrylamide gel electrophoresis (PAGE), densitometric analysis, normalization and interpolation of the protein profiles, and numerical analysis were performed as described by Pot et al. (34) with the GelCompar 3.1 software package (Applied Maths, Kortrijk, Belgium). The profiles were recorded and stored on a PC computer. The similarity between all pairs of traces was expressed by the Pearson product moment correlation coefficient $r$ converted for convenience to a percent value.

Fatty acid methyl ester analysis. After an incubation period of $48 \mathrm{~h}$, a loopful of well-grown cells was harvested, and fatty acid methyl esters were prepared, separated, and identified by using the Microbial Identification System (Microbial ID, Inc., Newark, Del.) as described before (47).

Preparation of high-molecular-weight DNA. Rapid, small-scale DNA extrac- tions for PCR analysis were performed as described by Pitcher et al. (33). Large-scale, high-molecular-weight native DNA was prepared as described before (47).

DNA fingerprinting. DNA fingerprinting by the PCR technique was performed as described before with Biomed PCR machines and Sphaero-Q Taq polymerase (Sphaero-Q, Leiden, The Netherlands) $(41,43)$. The primers $(50$ pmol per PCR mixture) listed in Table 2 were employed, either alone or in combination. Approximately $100 \mathrm{ng}$ of template DNA was added, and reaction products were separated on $2 \%$ agarose gels in $40 \mathrm{mM}$ Tris acetate (pH 7.8)-1 mM EDTA. Polaroid photographs were taken after ethidium bromide staining. DNA banding patterns were compared by visual inspection.

TABLE 2. Primers used for PCR fingerprinting of Capnocytophaga species

\begin{tabular}{llc}
\hline \multicolumn{1}{c}{ Code } & \multicolumn{1}{c}{ Base sequence } & Reference \\
\hline ERIC1 & CACTTAGGGGTCCTCGAATGTA & 49 \\
ERIC2 & AATAAGTGACTGGGGTGAGCG & 49 \\
REP1 & IIICGICGICATCTGGC & 49 \\
REP2 & ICGICTTATCTGGCCTAC & 49 \\
D14307 & CCTTGGGTGAGAATTGCACG & 1 \\
D9355 & CCGGATCCGTGATGCGGTGCG & 1 \\
D11344 & AGTGAATTCGCGGTGAGATGCCA & 1 \\
\hline
\end{tabular}


TABLE 3. Similarity matrix for Capnocytophaga strains based on $16 \mathrm{~S}$ rRNA sequence comparisons ${ }^{a}$

\begin{tabular}{|c|c|c|c|c|c|c|c|}
\hline \multirow[b]{2}{*}{ Species } & \multirow{2}{*}{$\begin{array}{c}\text { Sequence } \\
\text { accession } \\
\text { no. }^{b}\end{array}$} & \multirow[b]{2}{*}{ Reference } & \multicolumn{5}{|c|}{ Similarity } \\
\hline & & & $\begin{array}{l}\text { C. ochracea } \\
\text { ATCC } 27872^{\mathrm{T}}\end{array}$ & $\begin{array}{l}\text { C. ochracea } \\
\text { LMG } 12115\end{array}$ & $\begin{array}{l}\text { C. ochracea } \\
\text { LMG } 12117\end{array}$ & $\begin{array}{c}\text { C. ochracea } \\
\text { ATCC } 33596\end{array}$ & $\begin{array}{c}\text { C. sputigena } \\
{\text { ATCC } 33612^{\mathrm{T}}}^{\text {A }}\end{array}$ \\
\hline C. ochracea ATCC $27872^{\mathrm{T}}$ & $\mathrm{U} 41350$ & This study & & 98.7 & 98.1 & 97.4 & 95.8 \\
\hline C. ochracea LMG 12115 & U41353, U41354 & This study & 1.3 & & 98.3 & 98.0 & 96.3 \\
\hline C. ochracea LMG 12117 & U41351 & This study & 1.9 & 1.7 & & 97.4 & 95.8 \\
\hline C. ochracea ATCC 33596 & L14635 & 46 & 2.7 & 2.0 & 2.7 & & 96.4 \\
\hline C. sputigena ATCC $33612^{\mathrm{T}}$ & L14636 & 46 & 4.3 & 3.8 & 4.4 & 3.7 & \\
\hline C. haemolytica JCM $8565^{\mathrm{T}}$ & U41349 & This study & 8.0 & 8.6 & 8.4 & 9.1 & 9.0 \\
\hline C. cynodegmi ATCC $49044^{\mathrm{T}}$ & L14638 & 46 & 6.9 & 6.8 & 7.0 & 6.9 & 6.9 \\
\hline C. canimorsus ATCC $35979^{\mathrm{T}}$ & L14637 & 46 & 7.3 & 7.3 & 7.7 & 7.6 & 7.7 \\
\hline Capnocytophaga sp. strain LMG 12116 & U41352 & This study & 9.9 & 10.1 & 9.8 & 10.0 & 10.5 \\
\hline C. granulosa LMG 12119 & U41348 & This study & 9.0 & 8.7 & 9.1 & 8.8 & 8.9 \\
\hline C. granulosa JCM $8566^{\mathrm{T}}$ & U41347 & This study & 9.2 & 9.0 & 9.4 & 9.0 & 9.1 \\
\hline C. gingivalis LMG 12118 & U41346 & This study & 9.0 & 8.7 & 8.6 & 8.8 & 9.4 \\
\hline C. gingivalis ATCC $33624^{\mathrm{T}}$ & L14639 & This study & 8.6 & 8.6 & 8.6 & 8.8 & 8.7 \\
\hline Flavobacterium aquatile ATCC $11947^{\mathrm{T}}$ & M28236 & 55 & 13.3 & 12.7 & 13.2 & 13.1 & 13.5 \\
\hline Cytophaga uliginosa ATCC $14397^{\mathrm{T}}$ & M28238 & 55 & 14.9 & 14.1 & 14.5 & 14.6 & 15.3 \\
\hline
\end{tabular}

${ }^{a}$ Numbers above the diagonal are uncorrected percentages of similarity, and those below the diagonal are percentages of difference corrected for multiple base changes by the method described by Jukes and Cantor.

${ }^{b}$ 16S rRNA sequences for these strains are available for electronic retrieval from GenBank and EMBL under the indicated accession numbers.

Isolation and labeling of species-specific DNA probes. Species-specific DNA fragments were selected by comparison of PCR fingerprints. Fragments that appeared to be present in all banding patterns of a given species and apparently absent in all other species were excised from the agarose gels. DNA was purified by the Geneclean assay (Bio 101, La Jolla, Calif.), ethanol precipitated, and subsequently radioactively labeled by random-primed incorporation of $\left[\alpha-{ }^{32} \mathrm{P}\right] \mathrm{dATP}$ (Amersham; $3,000 \mathrm{Ci} / \mathrm{mmol}$ ) (15). The probes were hybridized at $42^{\circ} \mathrm{C}$ to South ern blots containing fingerprint DNA as described previously (20). The blots

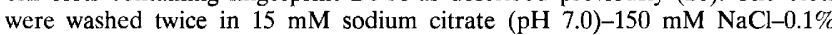
sodium dodecyl sulfate at $60^{\circ} \mathrm{C}$. Autoradiography was performed at $-70^{\circ} \mathrm{C}$ for at least $16 \mathrm{~h}$.

DNA base compositions. All of the mean mole percentage guanine-pluscytosine (mol\% $\mathrm{G}+\mathrm{C}$ ) values were determined by thermal denaturation and calculated by using the equation described by Marmur and Doty (28), as modified by De Ley (11).

DNA-DNA hybridization experiments. Degrees of DNA-DNA binding, expressed in percentages, were determined spectrophotometrically by the initia renaturation rate method described by De Ley et al. (12). Each value is the average of at least two hybridization experiments. Values of $30 \%$ DNA binding and less do not represent significant DNA homology. The total DNA concentration was about $60 \mu \mathrm{g} / \mathrm{ml}$, and the optimal renaturation temperature in $1 \times \mathrm{SSC}$ ( $1 \times \mathrm{SSC}$ is $0.15 \mathrm{M} \mathrm{NaCl}$ plus $0.015 \mathrm{M}$ sodium citrate) was $60.9^{\circ} \mathrm{C}$.

$16 \mathrm{~S}$ rRNA sequencing. With the exception of the type strains of $C$. haemolytica, $C$. granulosa, and $C$. ochraceae, $16 \mathrm{~S}$ rRNA sequencing was performed with purified rRNA as previously described (31). In addition to the standard sequenc ing primers (primers 2 to 5,9 , and 10 in Table 2 in Eaton et al. [14]), the following two primers were employed: X54 (5'-GGG GTT GCG CTC GTT ATA GGA CTT-3' $[1092$ to 1115 reverse]) and A44 (5'-ACT AGC GAT TCC AGC TTC-3' [1331 to 1348 reverse]).

The type strains of $C$. haemolytica, C. granulosa, and $C$. ochraceae were sequenced from PCR-amplified $16 \mathrm{~S}$ rDNA by using cycle sequencing as previously described (17).

Phylogenetic analysis of $16 \mathrm{~S}$ rRNA sequence information. The sequences were entered into RNA, a program for analysis of 16S rRNA data written in Microsof QuickBASIC for use on IBM-PC-compatible computers, and were aligned as previously described (31). The data base contains approximately 500 sequences determined in our laboratory and 400 sequences obtained from GenBank or from other researchers. Similarity matrices were constructed from aligned sequences by using only base positions for which $90 \%$ of the strains had data. The similarity matrices were corrected for multiple base changes by the method described by Jukes and Cantor (23). Phylogenetic trees were constructed by the neighbor-joining method (35).

Nucleotide sequence accession numbers. The GenBank and culture collection accession number for DF-3 strain LMG 11519 is U41355; all others are given in Table 3.

\section{RESULTS}

PAGE of whole-cell proteins. Duplicate protein extracts of several strains were prepared to check the reproducibility of growth conditions and extractions. The correlation level between duplicate protein patterns was $r \geq 0.93$. After visual comparison of the protein patterns with the dendrogram obtained after numerical comparison and clustering of the profiles, we delineated seven stable clusters and 3 separate strains at a similarity level of $85 \%$ (Fig. 1). Cluster I consists of three C. canimorsus reference strains and two field isolates. Cluster II consists of the four reference strains of $C$. cynodegmi clustering at higher than $88 \%$. Cluster III contains one $C$. ochracea reference strain and three field isolates. Cluster IV contains two $C$. ochracea reference strains grouping at $89 \%$. Cluster V contains two $C$. sputigena reference strains and three field isolates grouping at $87 \%$. Cluster VI contains the $C$. granulosa type strain and four field isolates grouping at $87 \%$. Finally, cluster VII contains the type strain of $C$. gingivalis and two field isolates grouping at a similarity level of greater than $87 \%$. C. haemolytica LMG $16021^{\mathrm{T}}$, strain LMG 12116 , and DF-3 strain LMG 11519 have distinct protein profiles and occupy separate positions in the dendrogram (Fig. 1).

Fatty acid methyl ester composition. The average fatty acid methyl ester compositions of each protein electrophoretic cluster of strains were calculated and are indicated in Table 4. Except for strain DF-3 LMG 11519, the general fatty acid patterns of the strains examined were very similar, with 14:0, 15:0 iso, 16:0, 16:0 $3 \mathrm{OH}$, and 17:0 iso $3 \mathrm{OH}$ as predominant components. $15: 0$ iso accounts for more than $55 \%$ of the total fatty acid contents of these strains. DF-3 strain LMG 11519 has a different fatty acid profile which is characterized by a large amount of 15:0 anteiso (37\%) and significant amounts (5 to $12 \%$ ) of $15: 0$ iso, $16: 03 \mathrm{OH}$, and $17: 0$ iso $3 \mathrm{OH}$. Furthermore, unique features for this strain were $14: 0$ iso, $16: 1 \mathrm{w} 7 \mathrm{c}, 16: 0$ iso $3 \mathrm{OH}$, and 17:0 2OH.

DNA fingerprinting. DNA of all strains (except LMG 11513, LMG 11519, LMG 16021, and LMG 16022) was subjected to nine amplification assays. It appeared that especially the combination of ERIC1 and ERIC2 primers enabled the generation of complex DNA fingerprints for all isolates (Fig. 2). The banding patterns reveal a relatively high degree of heterogeneity; all isolates except C. canimorsus LMG 11512 and 11541, which are subcultures of the same strain, and $C$. sputigena LMG 11508 and LMG 11509 display unique fingerprints. 
TABLE 3-Continued

\begin{tabular}{|c|c|c|c|c|c|c|c|c|c|}
\hline \multicolumn{10}{|c|}{ Similarity } \\
\hline $\begin{array}{l}\text { C. haemolytica } \\
\text { JCM } 8565^{\mathrm{T}}\end{array}$ & 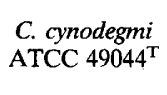 & $\begin{array}{l}\text { C. canimorsus } \\
\text { ATCC } 35979^{\mathrm{T}}\end{array}$ & $\begin{array}{l}\text { Capnocytophaga } \\
\text { sp. strain } \\
\text { LMG } 12116\end{array}$ & $\begin{array}{l}\text { C. granulosa } \\
\text { LMG } 12119\end{array}$ & $\begin{array}{l}\text { C. granulosa } \\
\text { JCM } 8566^{\mathrm{T}}\end{array}$ & $\begin{array}{l}\text { C. gingivalis } \\
\text { LMG } 12118\end{array}$ & $\begin{array}{c}\text { C. gingivalis } \\
\text { ATCC } 33624^{\mathrm{T}}\end{array}$ & $\begin{array}{c}\text { Flavobacterium } \\
\text { aquatile } \\
\text { ATCC } 11947^{\mathrm{T}}\end{array}$ & $\begin{array}{l}\text { Cytophaga uliginosa } \\
\text { ATCC } 14397^{\mathrm{T}}\end{array}$ \\
\hline 92.4 & 93.4 & 93.0 & 90.7 & 91.6 & 91.4 & 91.6 & 91.8 & 87.8 & 86.5 \\
\hline 91.9 & 93.5 & 93.0 & 90.6 & 91.8 & 91.5 & 91.7 & 91.8 & 88.3 & 87.2 \\
\hline 92.0 & 93.3 & 92.6 & 90.8 & 91.5 & 91.2 & 91.8 & 91.9 & 87.9 & 86.8 \\
\hline 91.4 & 93.4 & 92.8 & 90.7 & 91.7 & 91.5 & 91.7 & 91.7 & 88.0 & 86.7 \\
\hline \multirow[t]{2}{*}{91.5} & 93.4 & 92.7 & 90.2 & 91.6 & 91.4 & 91.1 & 91.8 & 87.6 & 86.2 \\
\hline & 91.9 & 91.8 & 89.4 & 89.3 & 89.2 & 89.7 & 89.7 & 85.6 & 85.3 \\
\hline 8.6 & & 98.7 & 91.0 & 92.5 & 91.7 & 91.7 & 92.2 & 88.5 & 87.0 \\
\hline 8.6 & 1.3 & & 90.6 & 92.0 & 91.2 & 91.6 & 91.8 & 88.9 & 87.2 \\
\hline 11.4 & 9.6 & 10.0 & & 96.1 & 96.0 & 95.4 & 95.7 & 86.8 & 84.8 \\
\hline 11.5 & 7.9 & 8.5 & 4.0 & & 99.4 & 98.1 & 98.6 & 88.2 & 86.3 \\
\hline 11.7 & 8.8 & 9.4 & 4.1 & 0.6 & & 97.6 & 98.4 & 87.7 & 85.9 \\
\hline 11.0 & 8.8 & 8.9 & 4.7 & 1.9 & 2.5 & & 98.5 & 87.1 & 85.9 \\
\hline 11.1 & 8.3 & 8.7 & 4.4 & 1.4 & 1.6 & 1.5 & & 87.8 & 86.2 \\
\hline 16.0 & 12.4 & 12.0 & 14.5 & 12.8 & 13.5 & 14.1 & 13.3 & & 87.7 \\
\hline 16.4 & 14.3 & 14.0 & 17.0 & 15.1 & 15.6 & 15.7 & 15.2 & 13.5 & \\
\hline
\end{tabular}

When other primers were used, DNA was not amplified for all C. sputigena strains. Several conserved elements within these amplification patterns were found. For instance, all C. sputigena strains share several DNA amplification fragments when ERIC1 and ERIC2 sequences were used as primers (Fig. 2). One of these common fragments with an approximate molecular length of $400 \mathrm{bp}$ was used as a species-specific DNA probe (19). Application of either REP1 or D11344 sequences as primers generated species specific DNA fragments for $C$. canimorsus. In the case of REP1-primed PCR, a species-specific DNA fragment of approximately $700 \mathrm{bp}$ was found, while in the case of D11344-primed PCR, at least four common fragments occurred (data not shown). DNA fragments specific for protein electrophoretic cluster VI (C. granulosa) and cluster VII ( $C$. gingivalis) strains were generated in several PCR assays. This was most apparent when the primers REP1 and REP2 were combined in one assay (Fig. 3A). The application of these DNA fragments as probes is illustrated in Fig. 3B and C. Two fragments (of approximately $500 \mathrm{bp}$ in length for $C$. granulosa and approximately $400 \mathrm{bp}$ in length for $C$. gingivalis) in Fig. 3A were excised, purified, and hybridized with a Southern blot made from the gel displayed in Fig. 3A. Clearly, both probes hybridize with all strains of the same cluster but not with other strains. We did not find DNA probes specific for C. ochracea or C. cynodegmi. Four of six $C$. ochracea strains form a genetically homogeneous group, whereas strains LMG 12115 and LMG 12117 behave aberrantly with most of the primers (Fig. 2; data not shown). The three $C$. cynodegmi strains examined also appear to be very different (Fig. 2; data not shown).

DNA base compositions. The DNA base ratios of representative strains per electrophoretic cluster were determined and are listed in Table 5.

DNA-DNA hybridization results. DNAs of $C$. gingivalis LMG $11514^{\text {T }}$ and of strains LMG 11515 and LMG 12116 were cross-hybridized. Only nonsignificant DNA-binding values of less than $30 \%$ were measured (results not shown).

16S rRNA sequence analysis. Approximately 1,450 bases of sequence information were determined for each strain listed in Table 3. Preliminary sequence comparisons demonstrated that all of the Capnocytophaga strains fell into a single monophyletic cluster. The DF-3 strain LMG 11519 was not part of the Capnocytophaga cluster but fell in the Bacteroides subgroup of the flavobacter-bacteroides phylum (18). A similarity matrix (Table 6) was determined for the aligned sequences of DF-3,
C. ochracea, $C$. gingivalis, and reference species from the flavobacter-bacteroides phylum. This matrix is based on comparisons at 1,422 base positions, for which more than $90 \%$ of the strains had data. The lower half of the matrix is expressed as percent differences corrected for multiple base changes by the method described by Jukes and Cantor (23). The neighborjoining tree for these organisms is shown in Fig. 4. A similarity matrix was also determined for the aligned sequences of the Capnocytophaga strains (Table 3). The tree for these strains is shown in Fig. 5.

\section{DISCUSSION}

Whole-cell protein analysis. We used a polyphasic approach to examine the taxonomic relationships among well-characterized strains representing all Capnocytophaga species and a number of field isolates. As a first step in the analysis, we compared the cellular protein patterns of all strains. Indeed, it has been established that by this technique, clusters of highly related strains, i.e., strains belonging to the same species, can be delineated $(7,30,44,45,47,48)$. Furthermore, this technique was successfully applied to subdivide a large number of Capnocytophaga field isolates (24). The results of the present study confirm these findings; except for $C$. ochracea, the reference strains of each species belong to a single electrophoretic cluster (Fig. 1). One reference strain of C. ochracea (LMG 11977) does not cluster with the other references of the same species, although Speck et al. (39) found high DNA homology values among the three strains. However, its protein profile, like those of the field isolates grouping in the same cluster (cluster III [Fig. 1]), contains a dense protein band with a somewhat lower molecular weight than that of the corresponding bands in the patterns of other $C$. ochracea reference strains. Such a variability in the molecular weight of dense protein bands among strains of a single species has been described for several genera (reviewed by Costas [7]). Often this variable region can be used for subspecific typing purposes, while it can be omitted from the numerical analysis in order to identify strains to the species level (7). The cluster III and IV strains are therefore to be considered as different protein electrophoretic types of $C$. ochracea.

Given the high similarity in protein content among the reference strains and the field isolates in each of these clusters, we conclude that strain LMG 11551 is C. canimorsus (cluster 1); 


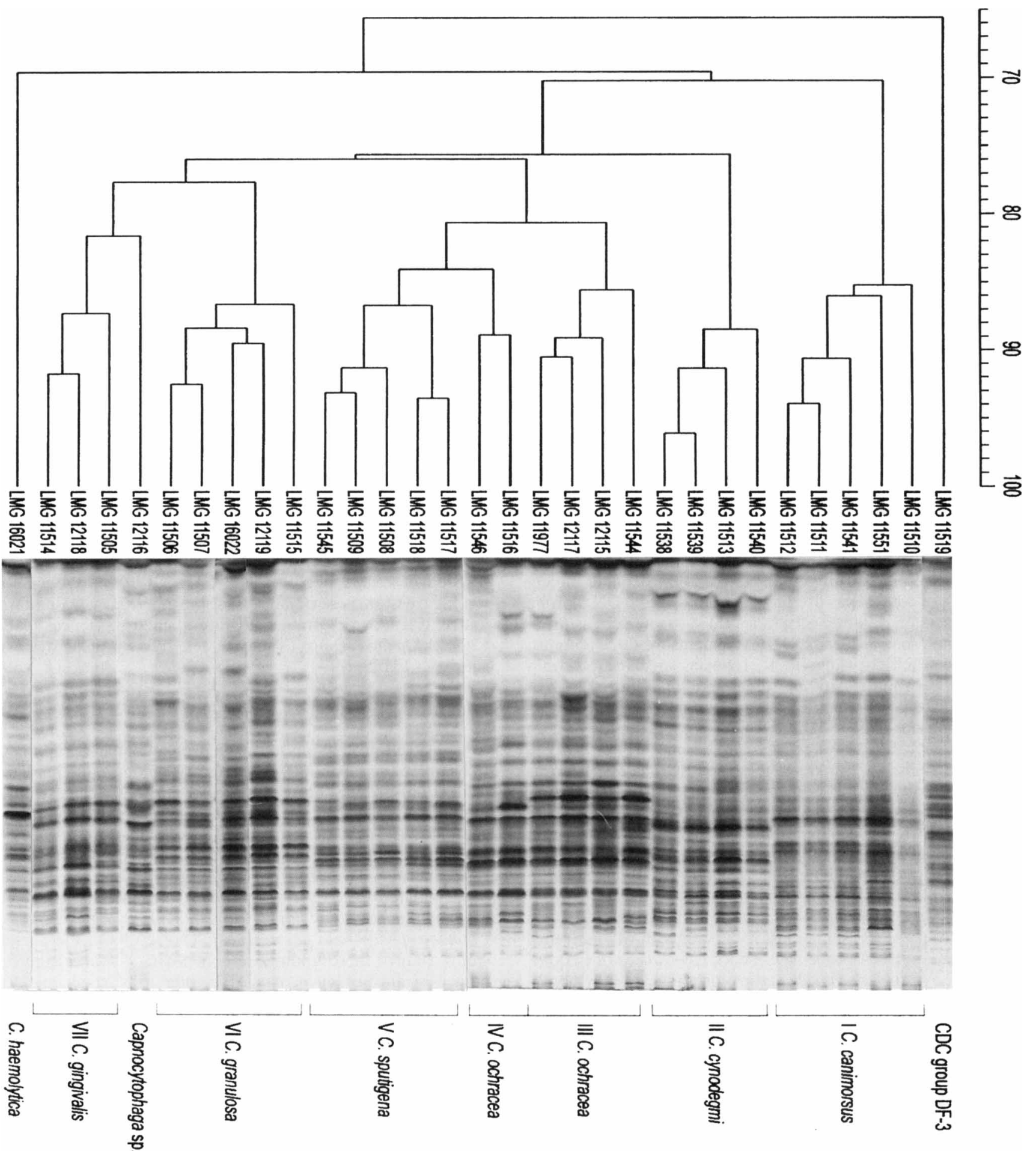

FIG. 1. Protein profiles of Capnocytophaga and Capnocytophaga-like strains and corresponding dendrogram derived from the unweighted pair group average linkage of correlation coefficients expressed for convenience as percentages. Roman numerals are cluster numbers as discussed in the text.

strains LMG 11544, LMG 12115, and LMG 12117 are $C$. ochracea (cluster III); strains LMG 11545, LMG 11508, and LMG 11509 are C. sputigena (cluster V); strains LMG 11515, LMG 12119, LMG 11507, and LMG 11506 are C. granulosa (cluster VI); and strains LMG 12118 and LMG 11505 are $C$. gingivalis (cluster VII). Only a single Capnocytophaga field isolate, LMG 12116, remained unidentified after protein anal- ysis. These identification results were further substantiated by the results of various other approaches described below.

16S rRNA sequence analysis. The $16 \mathrm{~S}$ rRNA sequences of the type strains of $C$. canimorsus, $C$. cynodegmi, $C$. gingivalis, $C$. ochracea, and $C$. sputigena and the taxonomic structure and neighborhood of the genus Capnocytophaga have been reported previously (46). Analysis of the $16 \mathrm{~S}$ rRNA sequences of 

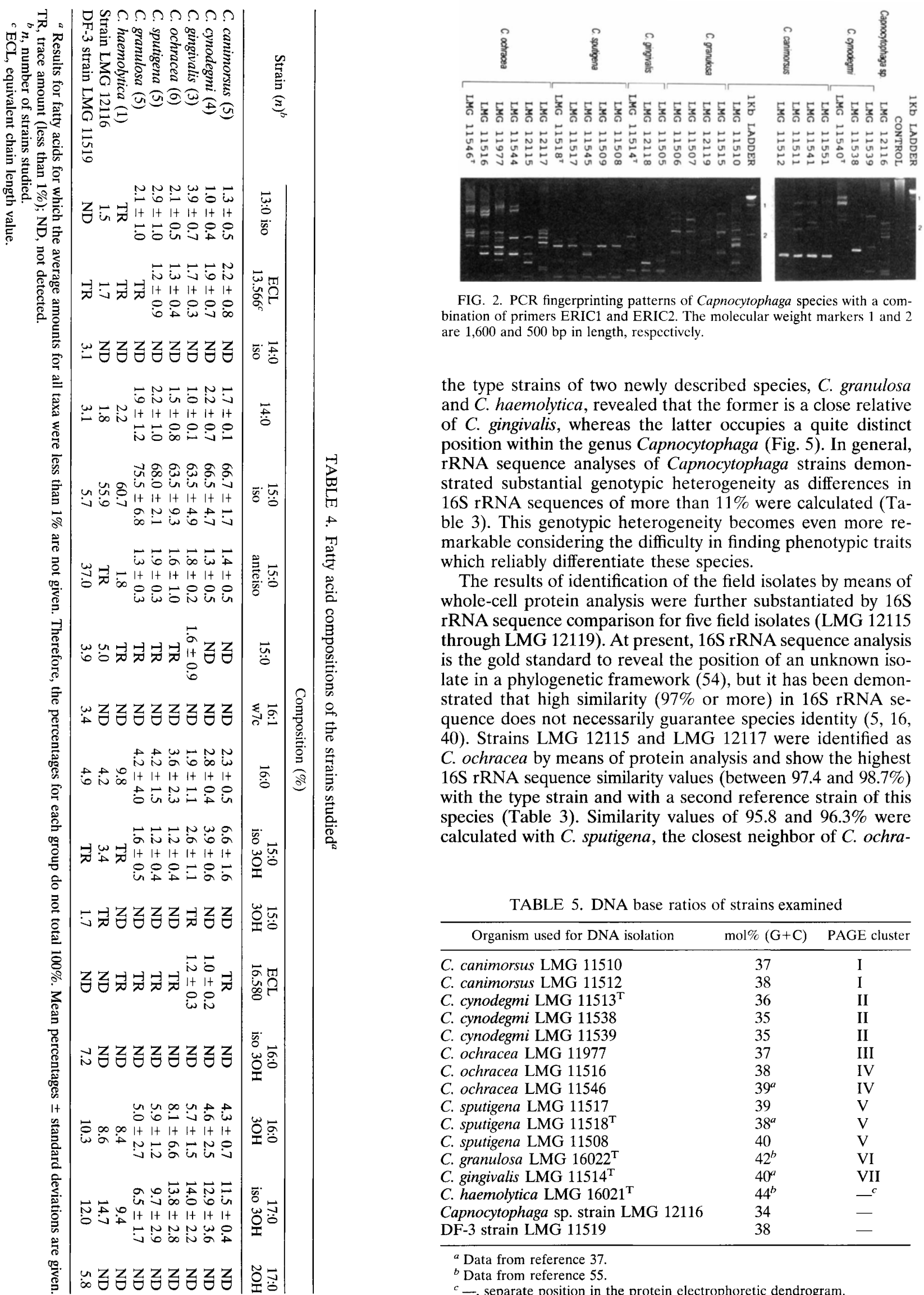

FIG. 2. PCR fingerprinting patterns of Capnocytophaga species with a combination of primers ERIC1 and ERIC2. The molecular weight markers 1 and 2 are 1,600 and $500 \mathrm{bp}$ in length, respectively.

the type strains of two newly described species, C. granulosa and $C$. haemolytica, revealed that the former is a close relative of $C$. gingivalis, whereas the latter occupies a quite distinct position within the genus Capnocytophaga (Fig. 5). In general, rRNA sequence analyses of Capnocytophaga strains demonstrated substantial genotypic heterogeneity as differences in 16S rRNA sequences of more than $11 \%$ were calculated (Table 3 ). This genotypic heterogeneity becomes even more remarkable considering the difficulty in finding phenotypic traits which reliably differentiate these species.

The results of identification of the field isolates by means of whole-cell protein analysis were further substantiated by $16 \mathrm{~S}$ rRNA sequence comparison for five field isolates (LMG 12115 through LMG 12119). At present, 16S rRNA sequence analysis is the gold standard to reveal the position of an unknown isolate in a phylogenetic framework (54), but it has been demonstrated that high similarity ( $97 \%$ or more) in $16 \mathrm{~S}$ rRNA sequence does not necessarily guarantee species identity $(5,16$, 40). Strains LMG 12115 and LMG 12117 were identified as C. ochracea by means of protein analysis and show the highest 16S rRNA sequence similarity values (between 97.4 and $98.7 \%$ ) with the type strain and with a second reference strain of this species (Table 3). Similarity values of 95.8 and $96.3 \%$ were calculated with $C$. sputigena, the closest neighbor of $C$. ochra-

TABLE 5. DNA base ratios of strains examined

\begin{tabular}{|c|c|c|}
\hline Organism used for DNA isolation & $\mathrm{mol} \%(\mathrm{G}+\mathrm{C})$ & PAGE cluster \\
\hline C. canimorsus LMG 11510 & 37 & I \\
\hline C. canimorsus LMG 11512 & 38 & I \\
\hline C. cynodegmi LMG $11513^{\mathrm{T}}$ & 36 & II \\
\hline C. cynodegmi LMG 11538 & 35 & II \\
\hline C. cynodegmi LMG 11539 & 35 & II \\
\hline C. ochracea LMG 11977 & 37 & III \\
\hline C. ochracea LMG 11516 & 38 & IV \\
\hline C. ochracea LMG 11546 & $39^{a}$ & IV \\
\hline C. sputigena $\mathrm{LMG} 11517$ & 39 & V \\
\hline C. sputigena $\mathrm{LMG} 11518^{\mathrm{T}}$ & $38^{a}$ & V \\
\hline C. sputigena LMG 11508 & 40 & V \\
\hline C. granulosa $\mathrm{LMG} 16022^{\mathrm{T}}$ & $42^{b}$ & VI \\
\hline C. gingivalis LMG $11514^{\mathrm{T}}$ & $40^{a}$ & VII \\
\hline C. haemolytica LMG $16021^{\mathrm{T}}$ & $44^{b}$ & $-c$ \\
\hline Capnocytophaga sp. strain LMG 12116 & 34 & - \\
\hline DF-3 strain LMG 11519 & 38 & - \\
\hline
\end{tabular}

${ }^{a}$ Data from reference 37.

${ }^{b}$ Data from reference 55 .

${ }^{c}-$, separate position in the protein electrophoretic dendrogram. 
TABLE 6. Similarity matrix for species in the flavobacter-bacteroides phylum based on $16 \mathrm{~S}$ rRNA sequence comparisons ${ }^{a}$

\begin{tabular}{|c|c|c|c|c|c|c|c|c|c|c|}
\hline \multirow[b]{2}{*}{ Species } & \multicolumn{10}{|c|}{ Similarity } \\
\hline & $\begin{array}{l}\text { Prevotella } \\
\text { melanino- } \\
\text { genica }\end{array}$ & $\begin{array}{c}\text { Prevotella } \\
\text { loescheii }\end{array}$ & $\begin{array}{l}\text { Bacteroides } \\
\text { fragilis }\end{array}$ & $\begin{array}{c}\text { Bacteroides } \\
\text { vulgatus }\end{array}$ & $\begin{array}{l}\text { Porphyromonas } \\
\text { gingivalis }\end{array}$ & $\begin{array}{l}\text { Porphyromonas } \\
\text { endodontalis }\end{array}$ & $\begin{array}{l}\text { [Bacteroides] } \\
\text { forsythus }\end{array}$ & $\begin{array}{l}\text { [Bacteroides] } \\
\text { distasonis }\end{array}$ & $\begin{array}{l}\text { CDC } \\
\text { group } \\
\text { DF-3 }\end{array}$ & $\begin{array}{c}\text { [Bacteroides] } \\
\text { splanch- } \\
\text { nicus }\end{array}$ \\
\hline Prevotella melaninogenica & & 89.8 & 84.5 & 84.3 & 81.0 & 80.8 & 82.7 & 80.8 & 81.7 & 81.8 \\
\hline Prevotella loescheii & 10.9 & & 83.1 & 83.9 & 81.3 & 80.7 & 81.6 & 81.4 & 80.4 & 80.8 \\
\hline Bacteroides fragilis & 17.4 & 19.1 & & 91.4 & 84.5 & 83.4 & 86.0 & 85.9 & 85.2 & 82.7 \\
\hline Bacteroides vulgatus & 17.7 & 18.1 & 9.1 & & 85.1 & 83.7 & 86.1 & 84.6 & 85.5 & 82.9 \\
\hline Porphyromonas gingivalis & 21.9 & 21.5 & 17.3 & 16.6 & & 88.3 & 87.5 & 84.3 & 84.6 & 82.0 \\
\hline Porphyromonas endodontalis & 22.1 & 22.4 & 18.8 & 18.4 & 12.7 & & 86.3 & 83.4 & 83.9 & 81.0 \\
\hline [Bacteroides] forsythus & 19.7 & 21.1 & 15.5 & 15.3 & 13.7 & 15.2 & & 89.0 & 88.1 & 84.9 \\
\hline [Bacteroides] distasonis & 22.2 & 21.3 & 15.7 & 17.3 & 17.6 & 18.7 & 11.9 & & 87.2 & 84.0 \\
\hline CDC group DF-3 & 21.0 & 22.7 & 16.4 & 16.2 & 17.2 & 18.1 & 12.9 & 14.0 & & 83.0 \\
\hline [Bacteroides] splanchnicus & 20.9 & 22.2 & 19.6 & 19.4 & 20.5 & 21.9 & 16.9 & 18.0 & 19.3 & \\
\hline [Cytophaga] fermentans & 22.0 & 23.1 & 18.3 & 19.4 & 19.5 & 18.1 & 17.2 & 18.8 & 17.4 & 17.3 \\
\hline [Cytophaga] salmonicolor & 21.1 & 23.6 & 17.8 & 17.9 & 18.8 & 18.4 & 17.6 & 18.7 & 16.8 & 15.2 \\
\hline [Bacteroides] putredinis & 22.5 & 22.6 & 21.6 & 22.7 & 19.9 & 20.0 & 18.0 & 20.3 & 19.0 & 18.5 \\
\hline Rikenella microfusus & 22.8 & 21.7 & 19.6 & 22.0 & 19.7 & 19.8 & 18.6 & 19.9 & 20.1 & 20.6 \\
\hline Sphingobacter mizutae & 24.4 & 24.7 & 23.9 & 23.5 & 21.8 & 21.9 & 21.7 & 22.0 & 22.7 & 23.3 \\
\hline [Flavobacterium] heparinum & 24.8 & 25.8 & 21.9 & 23.9 & 21.7 & 22.7 & 21.7 & 22.3 & 21.7 & 23.3 \\
\hline Capnocytophaga ochracea & 27.0 & 27.8 & 24.6 & 26.8 & 25.0 & 24.7 & 22.6 & 24.2 & 23.2 & 22.4 \\
\hline Capnocytophaga gingivalis & 24.7 & 26.9 & 24.2 & 25.1 & 24.1 & 23.2 & 22.4 & 23.7 & 21.8 & 21.9 \\
\hline Flavobacterium aquatile & 25.3 & 26.4 & 24.1 & 25.2 & 24.0 & 23.7 & 24.1 & 25.0 & 22.6 & 21.5 \\
\hline Cytophaga lytica & 24.9 & 25.9 & 22.3 & 23.6 & 22.8 & 21.7 & 22.4 & 24.3 & 22.4 & 22.7 \\
\hline $\begin{array}{l}\text { Chryseobacterium meningo- } \\
\text { septicum }\end{array}$ & 22.8 & 24.6 & 22.3 & 23.6 & 21.4 & 22.5 & 20.1 & 22.7 & 20.2 & 19.3 \\
\hline Chryseobacterium gleum & 25.0 & 27.2 & 23.8 & 24.7 & 24.3 & 24.7 & 23.6 & 26.3 & 23.6 & 22.7 \\
\hline Saprospira grandis & 29.0 & 28.8 & 29.5 & 30.0 & 27.4 & 27.8 & 28.7 & 30.7 & 30.2 & 25.9 \\
\hline [Flavobacterium] ferrugineum & 29.2 & 31.3 & 25.4 & 27.4 & 28.9 & 29.3 & 26.5 & 26.0 & 27.3 & 26.4 \\
\hline
\end{tabular}

${ }^{a}$ Numbers above the diagonal are uncorrected percentages of similarity, and those below the diagonal are percentages of difference corrected for multiple base changes by the method described by Jukes and Cantor.

cea (Table 3; Fig. 5). Likewise, strain LMG 12118 shares the highest similarity value $(98.5 \%)$ with the $C$. gingivalis type strain (LMG 11514 ${ }^{\mathrm{T}}$ ), and strain LMG 12119 shares the highest similarity value $(99.4 \%)$ with the $C$. granulosa type strain (LMG $\left.16022^{\mathrm{T}}\right)$. It is striking that these last two type strains share about $98.4 \%$ of their rRNA sequence, while only low-level or nonsignificant DNA-DNA binding was detected between these strains (this study; data not shown) (56). An even lower level of 16S rRNA similarity (97.4\%) was detected between two different reference strains of $C$. ochracea (ATCC $27872^{\mathrm{T}}$ and ATCC 33596 [LMG 11546]). However, these two strains share approximately $80 \%$ DNA-DNA homology $(52,56)$. As explained above, the percentage similarity in whole-cell protein content confirmed the DNA-DNA hybridization value in both cases. These findings corroborate that, also in the genus Capnocytophaga, $16 \mathrm{~S}$ rRNA sequence analysis is an excellent tool to allocate strains into a phylogenetic tree but not to identify strains at the species level (40). They also confirm that high similarity in whole-cell protein content is a parameter for high genomic relatedness, as revealed by DNA-DNA hybridization studies confirming the general applicability of this technique (7).

As discussed above, strain LMG 12116 remained unidentified after whole-cell protein analysis. 16S rRNA sequence analysis demonstrated that this strain belongs to the genus Capnocytophaga but revealed a rather isolated position in the dendrogram, with $C$. gingivalis and $C$. granulosa as its closest neighbors (95.4 to $96.1 \%$ 16S rRNA similarity [Table 3]). The general conclusion of Stackebrandt and Goebel (40) that strains sharing less than 97\% 16S rRNA similarity do not belong to the same species is confirmed here, since DNA-DNA hybridization experiments between strain LMG 12116 and the type strains of $C$. gingivalis and $C$. granulosa yielded only nonsignificant DNA-binding values (data not shown). This indicates that strain LMG 12116 represents a new species within the genus Capnocytophaga. The DNA base ratio of this species is rather low (34\% was calculated for strain LMG 12116 [Table $5]$ ), which further expands the range within the genus Capnocytophaga from 34 to $44 \mathrm{~mol} \% \mathrm{G}+\mathrm{C}$.

Comparative analysis of the $16 \mathrm{~S}$ rRNA sequence of DF-3 strain LMG 11519 revealed that this organism does not belong to the genus Capnocytophaga, since similarity values of approximately $80 \%$ were calculated (Table 6 ). An extensive comparison with representative organisms belonging to different lineages within the gram-negative bacteria showed that the DF-3 isolate, which is a typical representative of its group (50), fell into a cluster (Fig. 4) with [Bacteroides] forsythus and [Bacteroides] distasonis (names in brackets refer to generically misclassified species). This result is consistent with cellular fatty acid analysis which had shown that the DF-3 group had a fatty acid profile that was distinctly different from those of Capnocytophaga species (Table 4) (50). The biochemical similarities and the superficial similarities in fatty acid composition did not necessarily indicate a close genotypic relatedness between capnocytophagas and DF-3 strains, as assumed by several investigators $(8,50)$. Capnocytophaga species possess high-percentages 13-methyltetradecanoate (15:0 iso) (50) (Table 4), whereas the DF-3 group strains, $[B$.] forsythus and $[B$.$] dista-$ sonis, are characterized by significant levels (24 to $38 \%)$ of 12-methyltetradecanoate (15:0 anteiso) and only low to moderate levels (1 to 6\%) of 15:0 iso (36) (Table 4). The DF-3 group strains, $[B$.$] forsythus, and [B$.$] distasonis, form a new$ genus which branches next to the genus Porphyromonas (32). Formal description of this new genus will be made elsewhere.

Random- or repetitive element-primed PCR fingerprinting has been successfully used to type individual strains within a variety of microorganisms (42), and amplified fragments have been excised and used as species-specific probes in Campylobacter, Naegleria, Chlamydia, and Yersinia species (19). C. gin- 
TABLE 6-Continued

\begin{tabular}{|c|c|c|c|c|c|c|c|c|c|c|c|c|c|}
\hline \multicolumn{14}{|c|}{ Similarity } \\
\hline $\begin{array}{l}\text { [Cytophaga] } \\
\text { fermentans }\end{array}$ & $\begin{array}{c}\text { [Cytophaga] } \\
\text { salmoni- } \\
\text { color }\end{array}$ & $\begin{array}{c}\text { [Bacteroides }] \\
\text { putredinis }\end{array}$ & $\begin{array}{l}\text { Rikenella } \\
\text { micro- } \\
\text { fusus }\end{array}$ & $\begin{array}{c}\text { Sphingo- } \\
\text { bacter } \\
\text { mizutae }\end{array}$ & $\begin{array}{c}{[\text { Flavo- }} \\
\text { bacterium }] \\
\text { heparinum }\end{array}$ & $\begin{array}{c}\text { Capnocyto- } \\
\text { phaga } \\
\text { ochracea }\end{array}$ & $\begin{array}{c}\text { Capnocyto- } \\
\text { phaga } \\
\text { gingivalis }\end{array}$ & $\begin{array}{c}\text { Flavo- } \\
\text { bacterium } \\
\text { aquatile }\end{array}$ & $\begin{array}{c}\text { Cytophaga } \\
\text { lytica }\end{array}$ & $\begin{array}{c}\text { Chryseo- } \\
\text { bacterium } \\
\text { meningo- } \\
\text { septicum }\end{array}$ & $\begin{array}{l}\text { Chryseo- } \\
\text { bacterium } \\
\text { gleum }\end{array}$ & $\begin{array}{l}\text { Sapro- } \\
\text { spira } \\
\text { grandis }\end{array}$ & $\begin{array}{c}{[\text { Flavo- }} \\
\text { bacterium }] \\
\text { ferrugineum }\end{array}$ \\
\hline 81.0 & 81.6 & 80.6 & 80.3 & 79.1 & 78.9 & 77.3 & 78.9 & 78.5 & 78.8 & 80.3 & 78.8 & 75.9 & 75.8 \\
\hline 80.1 & 79.7 & 80.5 & 81.2 & 79.0 & 78.1 & 76.8 & 77.4 & 77.8 & 78.1 & 79.1 & 77.2 & 76.1 & 74.4 \\
\hline 83.8 & 84.1 & 81.3 & 82.7 & 79.5 & 81.0 & 79.0 & 79.4 & 79.4 & 80.7 & 80.7 & 79.6 & 75.6 & 78.5 \\
\hline 82.9 & 84.1 & 80.4 & 80.9 & 79.8 & 79.5 & 77.5 & 78.7 & 78.6 & 79.8 & 79.7 & 79.0 & 75.3 & 77.1 \\
\hline 82.8 & 83.3 & 82.5 & 82.6 & 81.1 & 81.2 & 78.8 & 79.4 & 79.4 & 80.4 & 81.4 & 79.3 & 77.1 & 76.0 \\
\hline 83.9 & 83.7 & 82.4 & 82.6 & 81.0 & 80.4 & 79.0 & 80.0 & 79.7 & 81.2 & 80.6 & 78.9 & 76.7 & 75.7 \\
\hline 84.6 & 84.3 & 84.0 & 83.5 & 81.2 & 81.1 & 80.5 & 80.6 & 79.4 & 80.6 & 82.4 & 79.7 & 76.1 & 77.7 \\
\hline 83.4 & 83.5 & 82.2 & 82.5 & 80.9 & 80.7 & 79.3 & 79.6 & 78.7 & 79.3 & 80.4 & 77.8 & 74.8 & 78.0 \\
\hline 84.5 & 85.0 & 83.2 & 82.4 & 80.4 & 81.1 & 80.1 & 81.0 & 80.5 & 80.6 & 82.3 & 79.7 & 75.1 & 77.1 \\
\hline \multirow[t]{2}{*}{84.5} & 86.2 & 83.6 & 82.0 & 80.0 & 80.0 & 80.6 & 81.0 & 81.3 & 80.4 & 83.0 & 80.4 & 78.1 & 77.7 \\
\hline & 90.6 & 84.7 & 86.9 & 83.8 & 83.4 & 84.3 & 85.5 & 85.9 & 85.9 & 85.7 & 82.7 & 78.7 & 78.9 \\
\hline 10.0 & & 85.1 & 86.3 & 83.7 & 83.3 & 81.9 & 84.0 & 83.0 & 83.4 & 85.6 & 83.4 & 78.9 & 79.0 \\
\hline 17.1 & 16.6 & & 88.8 & 81.9 & 82.2 & 80.6 & 81.3 & 81.7 & 81.2 & 84.1 & 82.3 & 79.6 & 78.1 \\
\hline 14.3 & 15.1 & 12.2 & & 83.7 & 83.1 & 81.1 & 81.6 & 81.1 & 82.7 & 83.8 & 82.2 & 77.4 & 76.6 \\
\hline 18.2 & 18.4 & 20.8 & 18.4 & & 89.6 & 79.8 & 81.1 & 79.6 & 81.4 & 83.8 & 81.9 & 79.1 & 76.3 \\
\hline 18.7 & 18.9 & 20.3 & 19.2 & 11.2 & & 79.5 & 82.0 & 81.0 & 82.1 & 82.8 & 79.1 & 79.1 & 78.6 \\
\hline 17.6 & 20.7 & 22.4 & 21.8 & 23.5 & 24.0 & & 92.0 & 88.1 & 87.9 & 85.4 & 83.1 & 78.7 & 78.7 \\
\hline 16.1 & 18.0 & 21.5 & 21.1 & 21.7 & 20.6 & 8.4 & & 88.4 & 88.5 & 85.8 & 84.1 & 78.7 & 79.7 \\
\hline 15.7 & 19.2 & 20.9 & 21.8 & 23.8 & 21.9 & 13.0 & 12.6 & & 90.0 & 86.5 & 83.8 & 79.5 & 80.2 \\
\hline 15.6 & 18.7 & 21.7 & 19.6 & 21.4 & 20.5 & 13.2 & 12.5 & 10.8 & & 85.7 & 82.3 & 78.8 & 78.4 \\
\hline 15.9 & 16.0 & 17.9 & 18.3 & 18.3 & 19.6 & 16.3 & 15.7 & 14.9 & 15.8 & & 94.4 & 82.4 & 79.8 \\
\hline 19.6 & 18.7 & 20.1 & 20.4 & 20.8 & 24.5 & 19.1 & 17.9 & 18.3 & 20.1 & 5.8 & & 80.8 & 78.6 \\
\hline 25.1 & 24.7 & 23.8 & 26.8 & 24.5 & 24.5 & 25.1 & 25.1 & 23.9 & 24.9 & 20.0 & 22.1 & & 79.5 \\
\hline 24.8 & 24.6 & 26.0 & 28.0 & 28.6 & 25.2 & 25.1 & 23.7 & 23.0 & 25.5 & 23.5 & 25.2 & 23.9 & \\
\hline
\end{tabular}
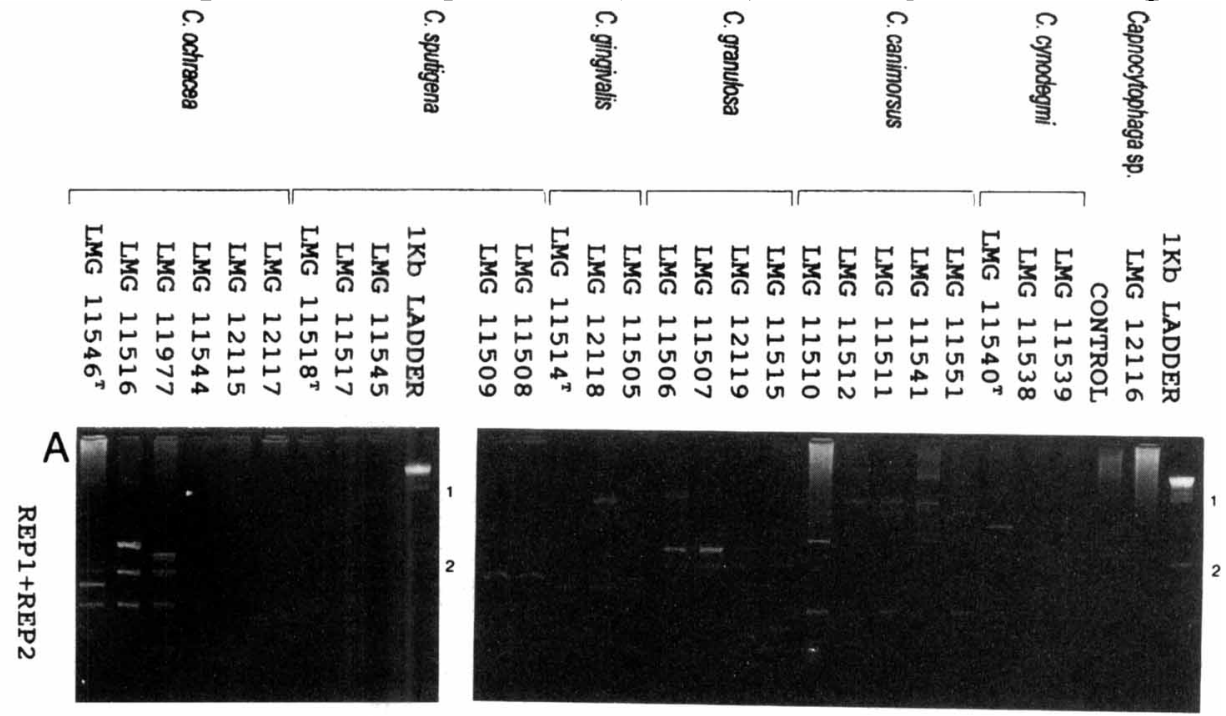

B
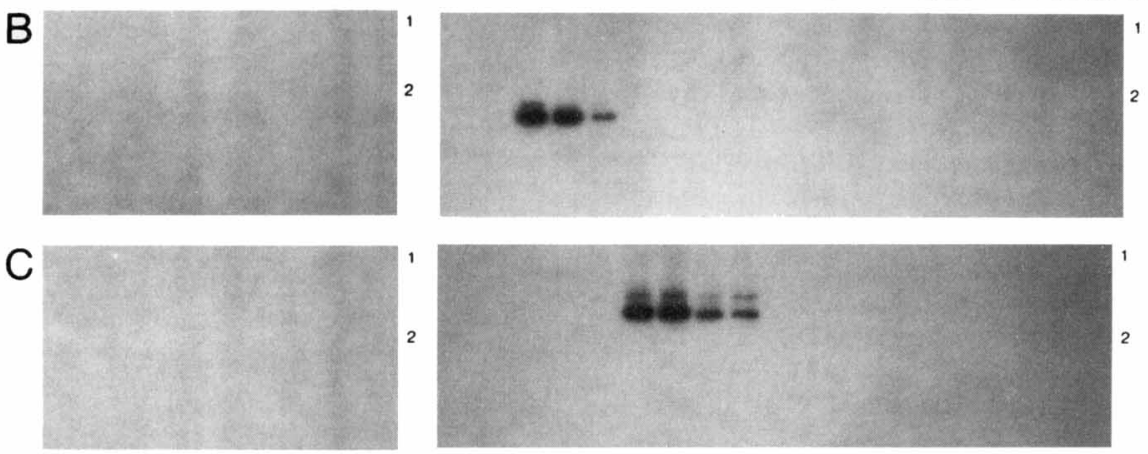

FIG. 3. PCR fingerprinting patterns and DNA probing of Capnocytophaga strains with a combination of REP1 and REP2 as PCR primers and species-specific DNA fragments as molecular probes. (A) Results of PCR analysis. The molecular weight markers 1 and 2 are 1,600 and 500 bp in length, respectively. (B and C) Probe hybridizations of Southern blots made from gels as displayed in panel A. 
(\% Difference)

तागाणा

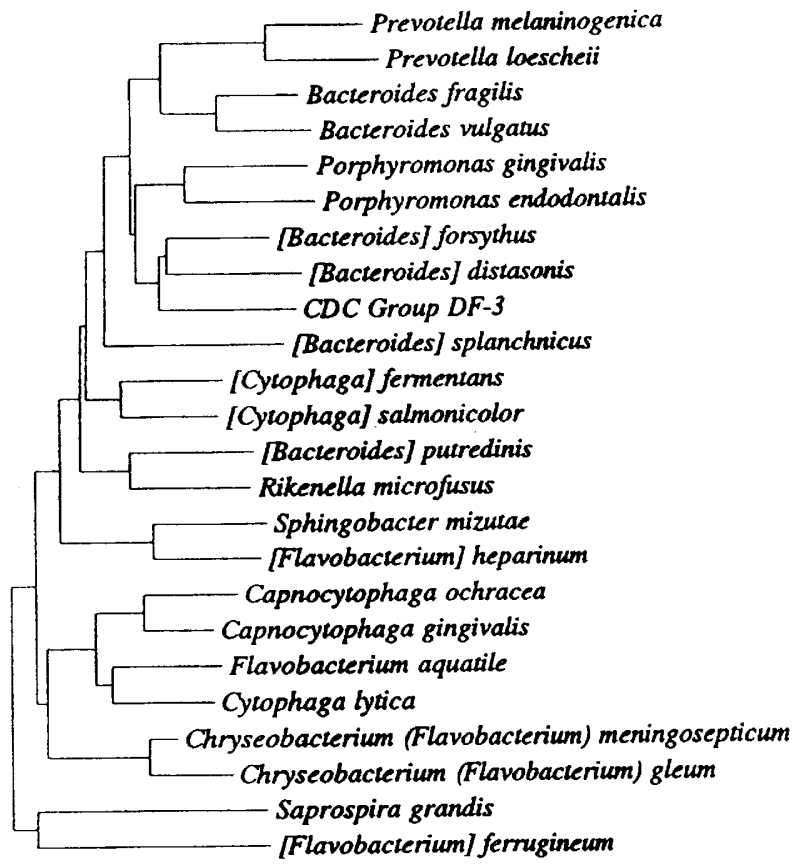

FIG. 4. Phylogenetic tree for CDC group DF-3, allied bacteria, and reference species based on $16 \mathrm{~S}$ rRNA sequence similarity. The scale bar represents $5 \%$ difference in nucleotide sequence as determined by measuring the lengths of the horizontal lines connecting any two species.

givalis, C. sputigena, $C$. canimorsus, and $C$. granulosa strains each give rise to similar DNA-banding patterns, underscoring the homogeneity of the species. For these species, DNA probes could be derived as a byproduct of the genotyping studies. In contrast, $C$. ochracea and C. cynodegmi appear to be more heterogeneous.

Finally, the data from fatty acid analysis confirm and extend the published data: all Capnocytophaga species, including the new species represented by strain LMG 12116, have very similar fatty acid components which are characterized by large amounts of branched-chain fatty acids, some of which are hy-

(\% Difference)

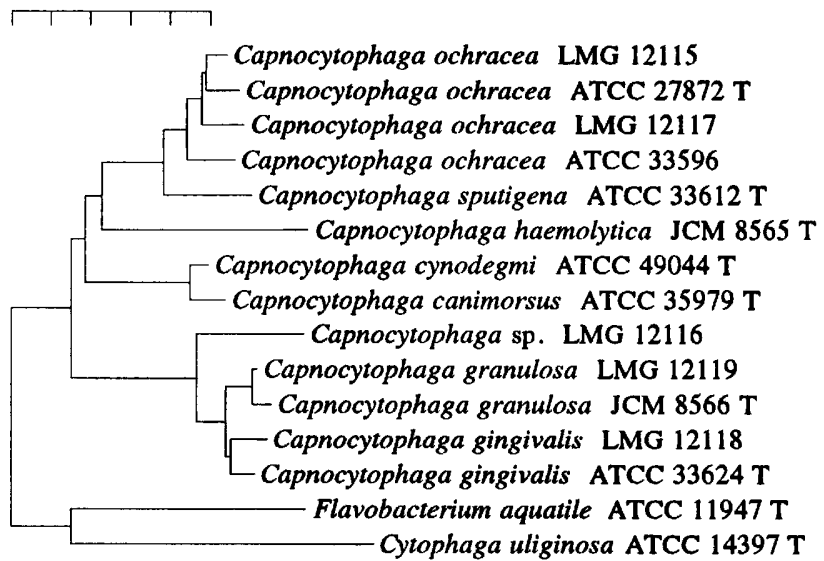

FIG. 5. Phylogenetic tree for Capnocytophaga and reference species based on $16 \mathrm{~S}$ rRNA sequence similarity. The scale bar represents $5 \%$ difference in nucleotide sequence as determined by measuring the lengths of the horizontal lines connecting any two species. droxylated (Table 2). Under our growth conditions, C. canimorsus strains are characterized by percentages of 15:0 iso $3 \mathrm{OH}$ that were higher than the others, whereas $C$. granulosa contains a very high percentage of 15:0 iso. Strain LMG 12116 differs from other Capnocytophaga species by the presence of 5\% 15:0, while this fatty acid is present in trace amounts in only some of the other species. Considering the standard deviations shown in Table 4, no other significant differences were detected.

In summary, we found a considerable genotypic heterogeneity within the genus Capnocytophaga, in spite of the minimal numbers of differentiating phenotypic features. These results showed that the degree of whole-cell protein similarity correlated with DNA-DNA homology and that percentage $16 \mathrm{~S}$ rRNA similarity values of greater than $97 \%$ did not guarantee conspecificity, which is in overall agreement with the general data from these techniques $(7,40)$. We also showed that CDC group DF-3 is not a close relative of the Capnocytophaga species but constitutes a separate genus together with $[B$.] forsythus and $[B$.$] distasonis, two generically misclassified Bacte-$ roides species.

\section{ACKNOWLEDGMENTS}

We thank Bart Hoste, Urbain Torck, and Dirk Dewettinck for excellent technical assistance.

P.V. is indebted to the National Fund for Scientific Research (Belgium) for a position as a postdoctoral research fellow. K.K. is indebted to the Fund for Medical Scientific Research (Belgium) for research and personnel grants. B.J.P. and F.E.D. were supported by grants I ROI DE08303 and I ROI DE10374 from the National Institute of Dental Research. We thank all depositors of strains listed in Table 1. Esmy Falcon is acknowledged for assistance with the initial PCR fingerprinting experiments.

\section{REFERENCES}

1. Akopyanz, N., N. O. Bukanov, T. U. Westblom, S. Kresovich, and D. E. Berg. 1992. DNA diversity among clinical isolates of Helicobacter pylori detected by PCR-based RAPD fingerprinting. Nucleic Acids Res. 20:5137-5142.

2. Bernard, K., C. Cooper, S. Tessier, and E. P. Ewan. 1991. Use of chemotaxonomy as an aid to differentiate among Capnocytophaga species, CDC group DF-3, and aerotolerant strains of Leptotrichia buccalis. J. Clin. Microbiol. 29:2263-2265.

3. Bernardet, J.-F., P. Segers, M. Vancanneyt, K. Kersters, and P. Vandamme. 1996. Cutting a Gordian knot: emended classification and description of the genus Flavobacterium, emended description of the family Flavobacteriaceae, and proposal of Flavobacterium hydatis nom. nov. (basonym, Cytophaga aquatilis Strohl and Tait 1978). Int. J. Syst. Bacteriol. 46:128-148.

4. Brenner, D. J., D. G. Hollis, G. R. Fanning, and R. E. Weaver. 1989. Capnocytophaga canimorsus sp. nov. (formerly CDC group DF-2), a cause of septicemia following dog bit, and $C$. cynodegmi sp. nov., a cause of localized wound infection following dog bite. J. Clin. Microbiol, 27:231-235.

5. Clayton, R. A., G. Sutton, P. S. Hinkle, C. Bult, and C. Fields. 1995. Intraspecific variation in small-subunit rRNA sequences in GenBank: why single sequences may not adequately represent prokaryotic taxa. Int. J. Syst. Bacteriol. 45:595-599.

6. Collins, M. D., H. N. Shah, A. S. McKee, and R. M. Kroppenstedt. 1982. Chemotaxonomy of the genus Capnocytophaga. J. Appl. Bacteriol. 52:409-415.

7. Costas, M. 1992. Classification, identification, and typing of bacteria by the analysis of their one-dimensional polyacrylamide gel electrophoretic protein patterns. Adv. Electrophor. 5:351-408.

8. Daneshvar, M. I., D. G. Hollis, and C. W. Moss. 1991. Chemical characterization of clinical isolates which are similar to CDC group DF-3 bacteria. J. Clin. Microbiol. 29:2351-2353.

9. Dees, S. B., D. E. Karr, D. Hollis, and C. W. Moss. 1982. Cellular fatty acids of Capnocytophaga species. J. Clin. Microbiol. 16:779-783.

10. Dees, S. B., J. Powell, C. W. Moss, D. G. Hollis, and R. E. Weaver. 1981 Cellular fatty acid composition of organisms frequently associated with human infections resulting from dog bites: Pasteurella multocida and groups EF-4, IIj, M-5, and DF-2. J. Clin. Microbiol. 14:612-616.

11. De Ley, J. 1970. Reexamination of the association between melting point buoyant density, and chemical base composition of deoxyribonucleic acid. J. Bacteriol. 101:738-754.

12. De Ley, J., H. Cattoir, and A. Reynaerts. 1970. The quantitative measurement of DNA hybridization from renaturation rates. Eur. J. Biochem. 12: $133-142$. 
13. Dewhirst, F. E., B. J. Paster, K.-H. Li, and G. J. Fraser. 1991. New human Capnocytophaga species by PAGE and 16S rRNA sequencing. J. Dent. Res. 70:319.

14. Eaton, K. A., F. E. Dewhirst, M. J. Radin, J. G. Fox, B. J. Paster, S Krakowka, and D. R. Morgan. 1993. Helicobacter acinonyx sp. nov., isolated from cheetahs with gastritis. Int. J. Syst. Bacteriol. 43:99-106.

15. Feinberg, A., and B. Vogelstein. 1993. A technique for radiolabeling DNA restriction endonuclease fragments to high specific activity. Anal. Biochem. 132:6-13.

16. Fox, G. E., J. D. Wisotzkey, and P. Jurtshuk. 1992. How close is close: 16S rRNA sequence identity may not be sufficient to guarantee species identity. Int. J. Syst. Bacteriol. 42:166-170.

17. Fox, J. G., L. L. Yan, F. E. Dewhirst, B. J. Paster, B. Shames, J. C. Murphy, A. Hayward, J. C. Belcher, and E. N. Mendes. 1995. Helicobacter bilis sp. nov., a novel Helicobacter species isolated from bile, livers, and intestines of aged, inbred mice. J. Clin. Microbiol. 33:445-454.

18. Gherna, R., and C. R. Woese. 1992. A partial phylogenetic analysis of the "flavobacter-bacteroides" phylum: basis for taxonomic restructuring. Syst. Appl. Microbiol. 15:513-521.

19. Giesendorf, B. A. J., W. G. V. Quint, P. Vandamme, and A. van Belkum. Generation of DNA probes for detection of microorganisms by polymerase chain reaction. Zentrl. Bakteriol., in press.

20. Giesendorf, B. A. J., A. van Belkum, A. Koeken, H. Stegeman, M. H. C. Henkens, J. Van Der Plas, H. Goossens, H. G. M. Niesters, and W. G. V. Quint. 1993. Development of species-specific DNA probes for Campylobacter jejuni, Campylobacter coli, and Campylobacter lari by polymerase chain reaction fingerprinting. J. Clin. Microbiol. 31:1541-1546.

21. Holt, S. C., G. Forcier, and B. J. Takacs. 1979. Fatty acid composition of gliding bacteria: oral isolates of Capnocytophaga compared with Sporocytophaga. Infect. Immun. 26:298-304.

22. Holt, S. C., E. R. Leadbetter, and S. S. Sokransky. 1979. Capnocytophaga: new genus of gram-negative gliding bacteria. II. Morphology and ultrastructure. Arch. Microbiol. 122:17-27.

23. Jukes, T. H., and C. R. Cantor. 1969. Evolution of protein molecules, p 21-132. In H. N. Munro (ed.), Mammalian protein metabolism, vol. 3. Academic Press, Inc., New York.

24. Khwaja, K. J., P. Parish, M. J. Aldred, and W. G. Wade. 1990. Protein profiles of Capnocytophaga species. J. Appl. Bacteriol. 68:385-390.

25. Kristiansen, J. E., A. Bremmegaard, H. E. Busk, O. Heltberg, W. Frederiksen, and T. Justersen. 1984. Rapid identification of Capnocytophaga isolated from septicaemic patient. Eur. J. Clin. Microbiol. 3:236-240.

26. Laughon, B. E., S. A. Syed, and W. J. Loesche. 1982. API ZYM system for the identification of Bacteroides spp., Capnocytophaga spp. and spirochaetes of oral origin. J. Clin. Microbiol. 15:97-102.

27. Leadbetter, E. R., S. C. Holt, and S. S. Sokransky. 1979. Capnocytophaga: new genus of gram-negative gliding bacteria. I. General characteristics, taxonomic considerations and significance. Arch. Microbiol. 122:9-16.

28. Marmur, J., and P. Doty. 1962. Determination of the base composition of deoxyribonucleic acid from its thermal denaturation temperature. J. Mol. Biol. 5:109-118.

29. Newman, M. G., V. L. Sutter, M. J. Pickett, U. Blachman, J. R. Greenwood, V. Grinenko, and D. Citron. 1979. Detection, identification and comparison of Capnocytophaga, Bacteroides ochraceus, and DF-1. J. Clin. Microbiol. 10:557-562.

30. Owen, R. J., and P. J. H. Jackman. 1982. The similarities between Pseudomonas paucimobilis and allied bacteria derived from analysis of deoxyribonucleic acids and electrophoretic protein patterns. J. Gen. Microbiol. 128: 2945-2954.

31. Paster, B. J., and F. E. Dewhirst. 1988. Phylogeny of campylobacters, wolinellas, Bacteroides gracilis, and Bacteroides ureolyticus by $16 \mathrm{~S}$ ribosomal ribonucleic acid sequencing. Int. J. Syst. Bacteriol. 38:56-62.

32. Paster, B. J., F. E. Dewhirst, I. Olsen, and G. J. Fraser. 1994. Phylogeny of Bacteroides, Prevotella, and Porphyromonas spp. and related bacteria. J. Bacteriol. 176:725-732.

33. Pitcher, D. G., N. A. Saunders, and R. J. Owen. 1989. Rapid extraction of bacterial genomic DNA with guanidium thiocyanate. Lett. Appl. Microbiol. 8:151-156.

34. Pot, B., P. Vandamme, and K. Kersters. 1994. Analysis of electrophoretic whole-organism protein fingerprints. In M. Goodfellow and A. G. O'Donnell (ed.), p. 493-521. Modern microbial methods. Chemical methods in prokaryotic systematics. J. Wiley and Sons, Ltd., Chichester, United Kingdom.

35. Saitou, N., and M. Nei. 1987. The neighbor-joining method: a new method for reconstructing phylogenetic trees. Mol. Biol. Evol. 4:406-425.

36. Sasser, M. 1995. Personal communication of cellular fatty acid composition provided from the anaerobic bacteria database. Microbial ID, Inc., Newark, Del.

37. Segers, P., W. Mannheim, M. Vancanneyt, K. De Brandt, K.-H. Hinz, K. Kersters, and P. Vandamme. 1993. Riemerella anatipestifer gen. nov., comb. nov., the causative agent of septicemia anserum exsudativa, and its phylogenetic affiliation within the Flavobacterium-Cytophaga rRNA homology group. Int. J. Syst. Bacteriol. 43:768-776.

38. Sokransky, S. S., S. C. Holt, E. R. Leadbetter, A. C. R. Tanner, E. Savitt, and B. F. Hammond. 1979. Capnocytophaga: new genus of gram-negative gliding bacteria. III. Physiological characterisation. Arch. Microbiol. 122:29-33.

39. Speck, H., R. M. Kroppenstedt, and W. Mannheim. 1987. Genomic relationships and species differentiation in the genus Capnocytophaga. Zentralbl. Bakteriol. Hyg. A 266:390-402.

40. Stackebrandt, E., and B. M. Goebel. 1994. Taxonomic note: a place for DNA-DNA reassociation and 16S rRNA sequence analysis in the present species definition in bacteriology. Int. J. Syst. Bacteriol. 44:846-849.

41. Struelens, M., E. Carlier, N. Maes, E. Serruys, W. Quint, and A. van Belkum. 1993. Nosocomial colonisation and infection with multiresistant Acinetobacter baumanii: outbreak delineation using DNA macrorestriction analysis and PCR fingerprinting. J. Hosp. Infect. 25:15-32.

42. van Belkum, A. 1994. DNA fingerprinting of medically important microorganisms by use of PCR. Clin. Microbiol. Rev. 7:174-184.

43. van Belkum, A., R. Bax, P. Peerbooms, W. H. F. Goessens, N. Van Leeuwen, and W. G. V. Quint. 1993. Comparison of phage typing and DNA fingerprinting by polymerase chain reaction for discrimination of methicillin-resistant Staphylococcus aureus strains. J. Clin. Microbiol. 31:798-803.

44. Vandamme, P., E. Falsen, B. Pot, B. Hoste, K. Kersters, and J. De Ley. 1989. Identification of $\mathrm{EF}$ group 22 campylobacters from gastroenteritis cases as Campylobacter concisus. J. Clin. Microbiol. 27:1775-1781.

45. Vandamme, P., B. Pot, E. Falsen, K. Kersters, and J. De Ley. 1990. Intraand interspecific relationships of veterinary campylobacters revealed by numerical analysis of electrophoretic protein profiles and DNA:DNA hybridizations. Syst. Appl. Microbiol. 13:295-303.

46. Vandamme, P. P. Segers, M. Vancanneyt, K. Van Hove, R. Mutters, J. Hommez, F. Dewhirst, B. Paster, K. Kersters, E. Falsen, L. Devrieze, K.-H Hinz, and W. Mannheim. 1994. Ornithobacterium rhinotracheale gen. nov., sp. nov. isolated from the avian respiratory tract. Int. J. Syst. Bacteriol. 44:24-37.

47. Vandamme, P., M. Vancanneyt, B. Pot, L. Mels, B. Hoste, D. Dewettinck, L. Vlaes, C. Van Den Borre, R. Higgins, J. Hommez, K. Kersters, J.-P. Butzler, and H. Goossens. 1992. Polyphasic taxonomic study of the emended genus Arcobacter with Arcobacter butzleri comb. nov. and Arcobacter skirrowii sp. nov., an aerotolerant bacterium isolated from veterinary specimens. Int. J. Syst. Bacteriol. 42:344-356.

48. Vauterin, L., P. Yang, B. Hoste, M. Vancanneyt, E. L. Civerolo, J. Swings, and K. Kersters. 1991. Differentiation of Xanthomonas campestris pv. citri strains by sodium dodecyl sulfate-polyacrylamide gel electrophoresis of proteins, fatty acid analysis, and DNA-DNA hybridization. Int. J. Syst. Bacteriol 41:535-542.

49. Versalovic, J., T. Koeuth, and J. R. Lupski. 1991. Distribution of repetitive DNA sequences in eubacteria and application to fingerprinting of bacterial genomes. Nucleic Acids Res. 19:6823-6831.

50. Wallace, P. L., D. G. Hollis, R. E. Weaver, and C. W. Moss. 1989. Characterization of CDC group DF-3 by cellular fatty acid analysis. J. Clin. Microbiol. 27:735-737.

51. Williams, B. L., and B. F. Hammond. 1979. Capnocytophaga: new genus of gram-negative gliding bacteria. IV. DNA base composition and sequence homology. Arch. Microbiol, 122:29-33.

52. Williams, B. L., D. Hollis, and L. V. Holdeman. 1979. Synonymy of strains of Center for Disease Control group DF-1 with species of Capnocytophaga. J. Clin. Microbiol. 10:550-556.

53. Wilson, M. J., W. G. Wade, and A. J. Weightman. 1995. Restriction fragment length polymorphism analysis of PCR-amplified 16S ribosomal DNA of human Capnocytophaga. J. Appl. Bacteriol. 78:394 401.

54. Woese, C. R. 1987. Bacterial evolution. Microbiol. Rev. 51:221-271.

55. Woese, C. R., D. Yang, L. Mandelco, and K. O. Stetter. 1990. The flexibacterflavobacter connection. Syst. Appl. Microbiol. 13:161-165.

56. Yamamoto, T., S. Kajiura, Y. Hirai, and T. Watanabe. 1994. Capnocytophaga haemolytica sp. nov. and Capnocytophaga granulosa sp. nov., from human dental plaque. Int. J. Syst. Bacteriol. 44:324-329. 